\title{
The Linkage between Sentiments and Stock Market Dynamics New Evidence from Iran
}

\author{
Heshmatollah Asgari ${ }^{1} \&$ Hamed Najafi ${ }^{2}$ \\ ${ }^{1}$ College of Economics, Ilam University, Tehran, Iran \\ ${ }^{2}$ College of Economics, Semnan University, Tehran, Iran \\ Correspondence: Hamed Najafi, College of Economics, Semnan University, Semnan, Iran. Tel: 98-912-844-8012. \\ E-mail: Hamed.najafi.eco@gmail.com and hamed.najafi@semnan.ac.ir
}

Received: October 21, 2020 Accepted: October 31, 2020 Online Published: November 1, 2020

doi:10.5430/jbar.v9n2p29 URL: https://doi.org/10.5430/jbar.v9n2p29

\begin{abstract}
In recent years, the issue of financial behavior and the impact of investors' sentiments on their decision making have become such a popular issue. The sentiments of financial activists affect the market price of financial assets and particularly stocks, and therefore it is included in the new pricing models of capital assets. In this article, we seek the effect of investors' sentiments on the dynamics of the Iranian stock market (TSE). To do this, among the companies accepted in the stock market we select 120, considering the research criteria and screening method, we examined TSE specifics throughout 2010-2018 using regression analysis and causality test. Our results show that firstly investors' sentiments have a direct effect on the stock returns and there is a bilateral relationship between them. Secondly, inflation has the opposite effect and economic growth has a direct and positive effect on the relationship between investor sentiment and stock returns. Finally, government spending has no significant effect on the relationship between investor sentiment and stock returns.
\end{abstract}

Keywords: sentiments, stock market return, stock price, Iran, inflation

\section{Introduction}

In recent years, Eugene Fama's Efficient-market hypothesis has been seriously criticized and this has led to a new approach to financial economics. Accordingly, many studies have been conducted in both economics and psychology on capital market puzzles and decision-making under uncertainty (Lee, Shleifer, and Thaler, 1991; Kumar and Lee, 2006; Baker and Wurgler, 2006, and Loewenstein et al. 2001). The view that stock prices fully reveal all necessary information should present a clear picture of investor's expectations nonetheless the presence of noise trader makes real stock price less important.

Several studies have documented that the classical theory in financial economics does not consider investor sentiment as a key factor to address the stock price (Thorbecke, 1997; Ehrmann \& Fratzscher, 2004; Maio, 2014; Kurov, 2010). On the other hand, there are studies that show the behavior of participants is not entirely rational and is unpredictable and accompanied by emotions (Kunming, 2010; Thaler, 1991) and there are shreds of evidence that investor's sentiment and emotions act as a systematic factor in stock prices (Baker \& Wurgler, 2006; Stambaugh, Yu, \& Yuan, 2012; Shen, Yu, \& Zhao, 2017).

Sentiments change the profitability of stocks and do so in the short term. For example, pessimism not only reduces stock returns but sometimes causes losses, and conversely, optimism can increase stock returns (Anusakumar et al., 2012). The stock price oscillates with the oscillation of investor's sentiment, but the impact due to positive and negative investor sentiment changes is different (Zhang \& Yang, 2009).

The existing literature shows that if there is an arbitrage constraint, an increase in optimism when emotions are on the rise will cause the market to be overestimated for a long period, and stock prices will distort its reasonable discounted value of the projected cash flows. (De Long et al., 1990; Mian \& Sankaraguruswamy, 2012; Kaplanski et al., 2015). Psychological studies have also found that emotions can affect the assessment of possible outcomes as well as the assessment of risk (Johnson \& Tversky, 1983; Loewenstein et al., 2001). Revealing the fundamentals of the market, following mispricing is adjusted, resulting in lower stock returns. In contrast, when sentiments are low, no attention is paid to them (Yu \& Yuan, 2011; Chong, Hong, \& Yeh, 2012), and therefore, there is no correction of 
errors about the latter sentiments (Yu \& Yuan, 2011; Chung, Hung, \& Yeh, 2012).

This study will try to shed some light on regional problems through the simultaneous analysis of the underlying factors making novel contributions to the literature. We aim to find a convincing answer to these questions: Does investor sentiment have a positive effect on stock returns? And does GDP have a positive impact on investor sentiment and stock exchange relationship? What are the role of Government expenditure and Inflation in the relationship between investor sentiment and stock exchange? Our approach to identifying the issue is distinct and two-fold: First, we examine the triple causality of these factors which is a new approach. Second, this study explains a challenging issue in the Tehran Stock Exchange (TSE) applying variables selected based on the state of the art theoretical foundations. We use data from the TSE data center, World Bank, and Statistical Center of Iran and with a sample of 2010-2018. The remained of this paper is organized as follows: Section 2 represents a summary and a table of literature preview. Section 3 describes the methodological framework and data sources; Section 4 reports and explains the results and, finally Section 5 offers concluding states with policy suggestions.

\section{Literature Preview}

A well-known set of studies of sentiment and aggregate stock returns appeared in the 1980s. They were largely theoretical, testing in various ways whether the stock market as a whole could be mispriced. In these studies, the role of sentiment was left implicit, and the statistical evidence was not usually very strong. More recent studies, such as Baker and Wurgler (2006), utilize interim advances in behavioral finance theory to provide sharper tests for the effects of sentiment. In particular, according to DeLong et al. (1990), there are two types of investors: rational arbitrageurs who are sentiment-free and irrational traders prone to exogenous sentiment. In such cases, mispricing arises out of the combination of two factors: a change in sentiment on the part of the irrational traders, and a limit to arbitrage from the rational ones. The key predictions of this framework come from its two moving parts. Consider first the possibility that sentiment-based demand shocks vary across firms, while arbitrage is equally difficult across firms. Hence when sentiment rises, we expect such "speculative" stocks to have simultaneously higher returns.

The question is what makes some stocks more profitable than others? It seems that the basic characteristics are difficulty and mental imagination in determining true value. For instance, in the case of start-ups that are unprofitable but potentially very profitable, a combination of unprofitable history and an uncertain but attractive future will allow investors to have valuations in a range of very small and very large value since emotions come into play. On the other hand, under the bubble situation when speculation tends to escalate, some young and ambiguous stocks are overvalued, while old firms with long term income, tangible assets, and stable dividends are much less assessed than mental value and may not be affected by sentiments.

\subsection{Sentiment Proxies}

Measuring investor sentiment is not that straightforward. Prior work suggests a number of proxies for sentiment to use as time-series conditioning variables. There are no definitive or uncontroversial measures, however. We can discuss some of the common themes in measuring sentiments and practical proxies. DeLong et al. (1990) suggested several methods of measuring sentiment including mood proxies; retail investor trades; mutual fund flows; trading volume; premium on dividend-paying stocks; closed-end fund discounts; option implied volatility; first-day returns on initial public offerings (IPOs); the volume of initial public offerings; new equity issues; and insider trading.

We follow Baker and Wurgler's (2007) six commonly employed proxies for measuring investor sentiment including: trading volume based on TSE turnover, the dividend premium, the closed-end fund discount, the first day returns on IPOs, and the equity share in new issues. We first explain each proxy singly and then discuss how they are formed into overall sentiment indexes.

The closed-end fund discount: The investor demand can cause a closed-end fund trading at a premium or a discount to its NAV (Net Asset Value). A premium price means the price of a share is above the NAV, while a discount is the opposite, below NAV, value.

Dividend premium: This is essentially a safety measure by which investors can assess the predictable flow of dividend payments. While dividends are in the high and strong stream, the company is likely to expect to disburse it, not as much of when it is on reduction (Fama \& French, 2001). According to Baker and Wurgler (2004) dividend premium is the difference between the average market-to-book value ratios of dividend payers and non-payers.

Initial public offerings (IPO): It is calculated as the log of number of IPOs issued during the specified period. In the case of TSE, there are studies that suggest there is a positive abnormal return to investing in the newly accepted oil and chemical firms for stockholders and the underpricing IPO phenomenon is confirmed (Karami et al., 2014; Filsaraei et al., 2013). 
IPO First day return: Often initial public offerings earn a great return on the very first day of trading that sentiment definitely is going to be involved (Zhang, 2008).

IPO volume: Investment decisions are highly dependent upon the volume of IPOs. This further relates that firms during the market enthusiasm period exploit by issuing new equity.

Trading volume: According to Elster (2003), emotions help in improve decision making by overcoming avoidable delays, hence resulting in a better quality decision without exclusive rational deliberation.

Although different studies have used different methods to measure investor sentiments, the findings of most studies show that high emotions have a negative effect on stock returns, and vice versa (Asem et al., 2016, Tran Nine, 2013; Grigaliūnienè \& Cibulskiene, 2010). So in this study, we are looking to answer the question of whether investor sentiments have a significant effect on the stock market dynamics in Iran or not? This research helps to identify the determinants of stock prices in the Iranian stock market. We will take a new look at the issue of behavioral finance and use the variables related to the Iranian stock market to measure the effect.

For a more comprehensive review of the literature, we represent the following table.

Table 1. Summary of empirical studies about the effect of sentiments on stock market dynamics

\begin{tabular}{|c|c|c|c|c|}
\hline Author & Subject & Period & method & Result \\
\hline Trichilli et al. (2020) & $\begin{array}{lrr}\text { Middle } & \text { East } & \text { and } \\
\text { North } & \text { Africa } \\
(\text { MENA) } & & \end{array}$ & $\begin{array}{l}2004 \\
2018\end{array}$ & $\begin{array}{l}\text { Hidden Markov model based } \\
\text { on the transition matrix }\end{array}$ & Sentiments effect is significant \\
\hline Rupande et al. (2019) & $\begin{array}{lr}\text { South } & \text { Africa } \\
\text { (Johannesburg } & \text { Stock } \\
\text { Exchange) } & \end{array}$ & $\begin{array}{l}2002 \\
2018\end{array}$ & $\begin{array}{l}\text { Generalized Autoregressive } \\
\text { Conditional } \\
\text { Heteroscedasticity model }\end{array}$ & Sentiment effect is significant \\
\hline He et al. (2019) & $\begin{array}{l}\text { USA } \\
\text { (US Stock Market) }\end{array}$ & $1987-2015$ & $\begin{array}{l}\text { TVA-GARCH-M model - } \\
\text { Maximum Likelihood }\end{array}$ & $\begin{array}{l}\text { Sentiment effect is significant } \\
\text { through the past risk }\end{array}$ \\
\hline $\begin{array}{l}\text { Padungsaksawasdi } \\
\text { (2019) }\end{array}$ & Thailand & $\begin{array}{l}2000 \\
2018\end{array}$ & $\begin{array}{l}\text { PVAR methodology with the } \\
\text { GMM estimation }\end{array}$ & $\begin{array}{l}\text { Investor sentiment } \rightarrow \text { stock } \\
\text { returns }\end{array}$ \\
\hline $\begin{array}{l}\text { Liston Perez and } \\
\text { Gutierrez }(2018)\end{array}$ & USA & $1988-2009$ & $\begin{array}{l}\text { Vector autoregressive model } \\
\text { (VAR) }\end{array}$ & $\begin{array}{l}\text { Both individual and institutional } \\
\text { rational-based sentiment } \\
\text { positively influence pure sin } \\
\text { returns }\end{array}$ \\
\hline Smales (2017) & NYSE & $1990-2015$ & Causality tests & $\begin{array}{l}\text { Sentiment } \rightarrow \text { return } \\
\text { (across firm-size and value) }\end{array}$ \\
\hline $\begin{array}{l}\text { Yang et al. (2017) and } \\
\text { Ryu et al. (2017) }\end{array}$ & $\begin{array}{l}\text { South Korea } \\
\text { (Korean } \\
\text { Market) }\end{array}$ & $2000-2015$ & $\begin{array}{l}\text { Multivariate regression } \\
\text { analyses for firm sizes and } \\
\text { stock prices }\end{array}$ & $\begin{array}{l}\text { Sentiment effect is significant } \\
\text { specially on small firms }\end{array}$ \\
\hline Iyer and Harper (2017) & European Union & $1980-2014$ & $\begin{array}{l}\text { Regression analysis (cash } \\
\text { flow volatility) }\end{array}$ & $\begin{array}{l}\text { Investor sentiment has little } \\
\text { influence on safe stocks }\end{array}$ \\
\hline Ben Aissia (2016) & $\begin{array}{l}\text { France } \\
\text { (French } \\
\text { Market) }\end{array}$ & $2003-2013$ & Regression analysis & Sentiment effect is significant \\
\hline Asem et al. (2016) & Australia & $2000-2012$ & Regression analysis & $\begin{array}{l}\text { Sentiments effect is significant } \\
\text { ( Specially for big firms) }\end{array}$ \\
\hline Liu Sh. (2015) & NYSE and AMEX & $1976-2007$ & Granger Causality Tests & Sentiment $\rightarrow$ market liquidity \\
\hline
\end{tabular}




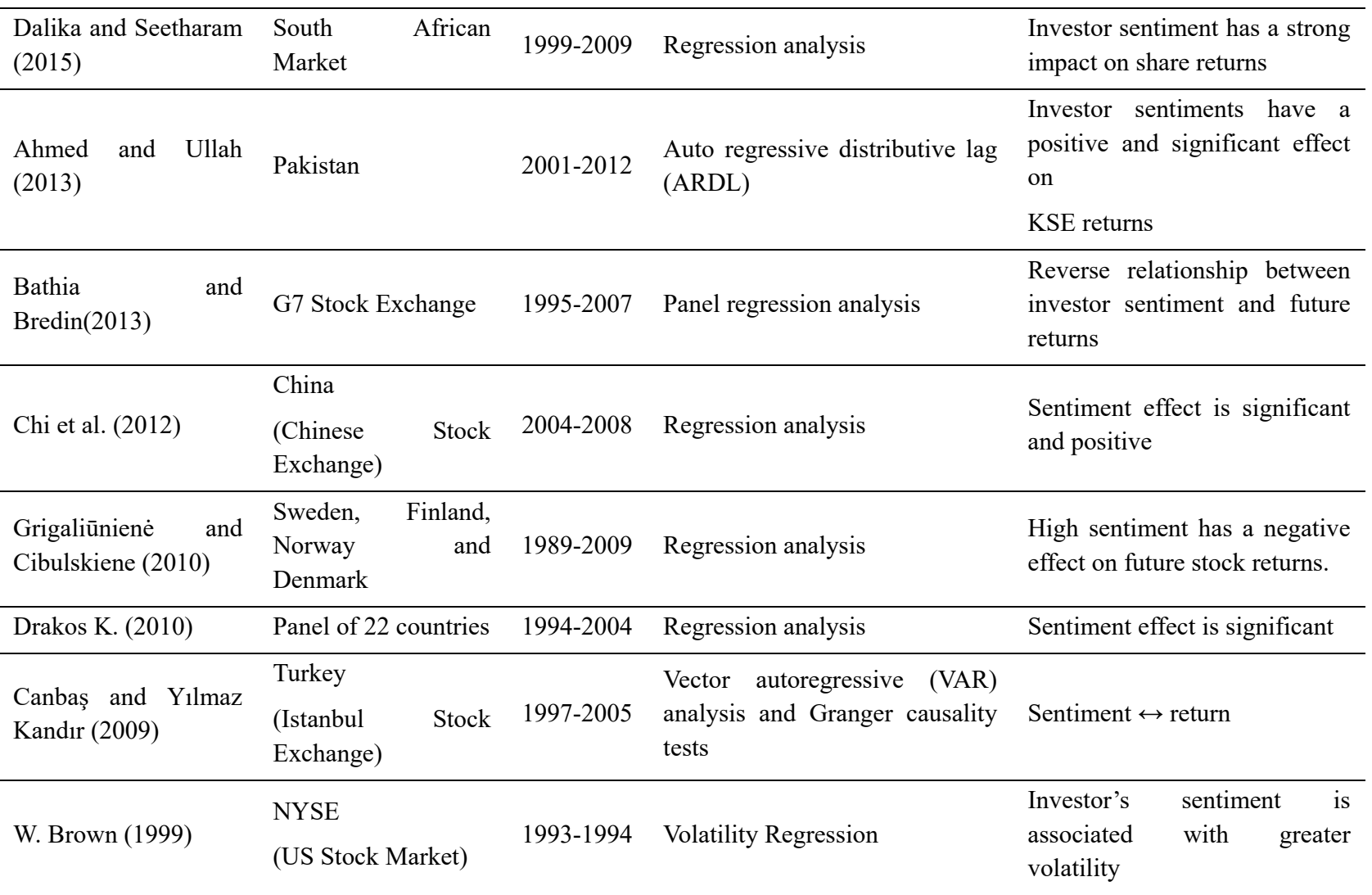

The sentiment is a combination of simple and complex mental evaluation process resulting in an emotional state of the body as additional mental change (Kuzmina, 2010). This can be both a reaction to certain stimuli and the human brain which prepares the body to react in certain directions. People with the goal of making the most profit in financial affairs, in addition, their sense of well-being is based on the best conjecture and experience of the past about the possible outcome. According to Kuzmina (2010) on average, emotional traders are positive about uncertainties. Therefore, they tend to buy risky assets. Noise traders are also an essential part of the price settlement mechanism. When the ratio of emotional investors is higher, the probability of return and market fluctuations is higher.

Behavioral asset pricing model conceives that irrational emotion and the market price of risk (MPR) are linked; where noise traders show melancholic, rational traders hold optimistic opinion thus risk compensation would be higher in this case to attract rational trade henceforth upward movement of MPR and likewise lower, where irrational investors are optimistic so that rational investors could do their investments (Rahul Vermaa, 2009; Ahmed \& Ullah, 2013). Based on the above discussion and the deep sentimental conditions of the market and the macroeconomic conditions of Iran, we intend to answer the questions of this study.

\section{Data and Methodology}

The data for research variables were obtained from the Tehran stock exchange, the World Bank database, and the central bank of Iran. All these sources are highly credible and frequently used by researchers to obtain reliable and accurate data for their variables. The data was a quarterly range from the first quarter of 2010 up till the last quarter of 2018. Variables that were not available quarterly, the value of these values were calculated on a monthly basis based on Denton's interpolation method in 1971. The effect of these values attributed in no way jeopardizes the integrity of our results, as this does not eliminate the effect of the original values.

\subsection{Analytical Model}

In order to test our hypotheses we will estimate the following baseline regression model:

$$
\begin{aligned}
& \mathrm{IR}=\mathrm{f}(\text { GDP, INF, GEXP, SENTI }) \\
& \mathrm{IR}=\alpha+\beta 1 \text { GDP } \mathrm{t}+\beta 2 \text { INF } \mathrm{t}+\beta 3 \text { GEXP } \mathrm{t}+\beta 4 \text { SENTI } \mathrm{t}
\end{aligned}
$$


Where:

TSER $=\mathrm{P}_{\mathrm{t}}-\mathrm{P}_{0} / \mathrm{P}_{0}$ Where IR $=$ Index returns, $\mathrm{P}_{\mathrm{t}}=$ current closing TSE index at time $\mathrm{t}$ and, $\mathrm{P}_{0}=$ closing TSE index at $\mathrm{t}-1$.

$\mathrm{GDP}=\Delta \mathrm{GDP}$ growth rate per quarter, measured as: $\mathrm{GDP}_{\mathrm{t}}-\mathrm{GDP}_{0} / \mathrm{GDP}_{0}$ where, $\mathrm{GDP}_{\mathrm{t}}=\mathrm{GDP}$ growth rate at time $\mathrm{t}$ and $\mathrm{GDP}_{0}=\mathrm{GDP}$ growth rate at $\mathrm{t}-1$;

$\mathrm{INF}=\Delta$ inflation rate per quarter, measured as: $\mathrm{CPI}_{\mathrm{t}}-\mathrm{CPI}_{0} / \mathrm{CPI}_{0}$ where, $\mathrm{CPI}_{\mathrm{t}}=$ inflation rate at time $\mathrm{t}$ and $\mathrm{CPI}_{0}=$ inflation rate at time $\mathrm{t}-1$;

$\mathrm{GEXP}=\Delta$ government expenditure rate per quarter, measured as: $\mathrm{GEXP}_{\mathrm{t}}-\mathrm{GEXP}_{0} / \mathrm{GEXP}_{0}$ where $\mathrm{GEXP}_{\mathrm{t}}=$ government expenditure at time $\mathrm{t}$ and $\mathrm{GEXP}_{0}=$ government expenditure at time $\mathrm{t}-1$;

SENTI $=$ Sentiment level is gauged by using the fluctuation of TSE total index.

\section{Empirical Result}

\subsection{ADF Test}

To prevent false regression, we first checked the variability of the variables and reported the results in the table 2 as follows.

Table 2. ADF Test Results

\begin{tabular}{|c|c|c|c|c|c|c|}
\hline \multicolumn{4}{|l|}{ At level } & \multicolumn{3}{|c|}{ At first difference } \\
\hline Variable & $\begin{array}{l}\text { With } \\
\text { intercept }\end{array}$ & $\begin{array}{l}\text { With trend and } \\
\text { intercept }\end{array}$ & None & $\begin{array}{l}\text { With } \\
\text { intercept }\end{array}$ & $\begin{array}{l}\text { With trend and } \\
\text { intercept }\end{array}$ & None \\
\hline TSER & & & & -2.936942 & -3.526609 & -1.949319 \\
\hline INF & -2.936942 & -3.526609 & -1.949097 & & & \\
\hline GDP & & & & -2.936942 & -3.526609 & -1.949319 \\
\hline GEXP & & & & -2.941145 & -3.533083 & -1.949856 \\
\hline SENTI & & & & -2.936942 & -3.526609 & -1.949319 \\
\hline
\end{tabular}

Significant at $5 \%$.

Then we examined the vectors of cointegration between the variables and no correlation was found. So we go to estimate the VAR model and then examine the causal relationships between the variables.

\subsection{Causality Test}

In this step, we examine the causal relationships between the variables. The most important result of the causality test is that investor sentiment has a two-way causal relationship with stock return. Also, inflation can be another factor in increasing the sentiment of capital market participants, and that is the Granger causality. Inflation can also increase stock market returns. However, no evidence was found for GDP and government spending on the causality of stock returns and sentiments. The result is shown in table 3 as follow: 
Table 3. Causality test

\begin{tabular}{ll}
\hline Dependent variable & Pairwise Granger test \\
\hline \multirow{3}{*}{ TSER } & SENTI $\rightarrow$ TSER \\
& INF $\rightarrow$ TSER \\
& GDP $\nRightarrow$ TSER \\
& GEXP $\nRightarrow$ TSER \\
\hline \multirow{3}{*}{ INF } & GDP $\rightarrow$ INF \\
& GEXP $\rightarrow$ INF \\
& SENTI $\nRightarrow$ INF \\
& TSER $\nRightarrow$ INF \\
\hline \multirow{3}{*}{ GDP } & TSER $\rightarrow$ GDP \\
& GEXP $\rightarrow$ GDP \\
& SENTI $\nRightarrow$ GDP \\
& INF $\nRightarrow$ GDP \\
\hline \multirow{3}{*}{ GEXP } & TSER $\nRightarrow$ GEXP \\
& GDP $\rightarrow$ GEXP \\
& SENTI $\nRightarrow$ GEXP \\
& INF $\nRightarrow$ GEXP \\
\hline & TSER $\rightarrow$ SENTI \\
& INF $\rightarrow$ SENTI \\
& GDP $\nRightarrow$ SENTI \\
& GEXP $\nRightarrow$ SENTI \\
\hline &
\end{tabular}

\subsection{Impulse Response Functions}

In this section, we present the results of the impulse response functions. An impulse response function shows the dynamic responses of the variables at a time to various shocks within the VAR system. These types of functions are used to analyze how shocks in any variable in the system filter thorough to affect every other variable. 
Response to Cholesky One S.D. (d.f. adjusted) Innovations
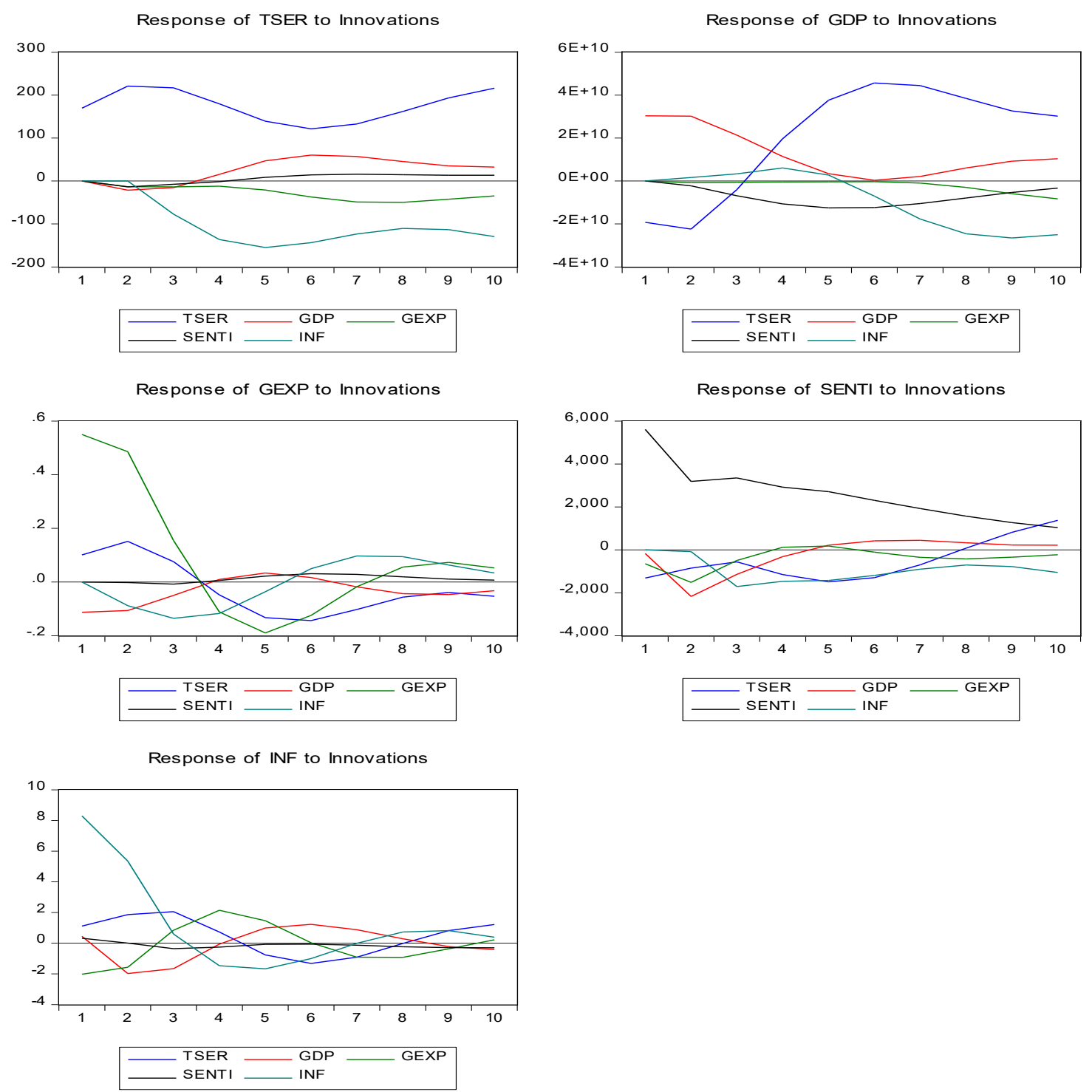

Figure 1. Impulse response functions of the VAR

In particular, based on Figure 1, we notice that investor sentiment has a positive impact on stock return and vice versa. The same holds true for the effect of market return on economic growth. Among the finding, the effect of inflation on investor sentiment is negative. Finally, results show that economic growth positively affects government spending and the inflation has an opposite effect and economic growth has a direct and positive effect on the relationship between investor sentiment and stock returns. With regard to government spending, we can report that it has no significant effect on the relationship between investor sentiment and stock returns.

\section{Conclusion}

In this article, we seek the effect of investors' sentiments on the dynamics of the Iranian stock market (TSE). To do this, among the companies accepted in the stock market, considering the research criteria and screening method, we examined 120 companies throughout 2011-2018 using regression analysis. Our results show that firstly investors' sentiments have a direct effect on the stock returns and there is a bilateral relationship between them. Secondly, inflation has the opposite effect and economic growth has a direct and positive effect on the relationship between investor sentiment and stock returns. Finally, government spending has no significant effect on the relationship between investor sentiment and stock returns. 
These days' Iranian investors have an optimistic outlook towards investment in TSE, hence depicting positive sentiment in this otherwise seemingly depressing condition of the economy. Sentiments do fluctuate according to the economic conditions of the country. The results highlight this point as inflation, one of the most important issues of this country has been found to negatively impact stock index returns, GDP to positively impact on stock index returns and sentiment to projecting positively and significantly in the short run.

Considering the causality test we find that there is a bilateral relationship between investor sentiment and stock return. Government spending causes inflation and inflation can cause investor sentiments. This optimistic attitude of most of the investors in Iran depicts the significance of the sentiment factor on the country's investment potential. Investors in the quest of implementing the momentum approach in Asia and possibly elsewhere should be watchful of the sentiment established at the time of portfolio formation. The results also signify that long-run sentiment and inflation have a significant role and confirm the logic of base papers with sentiment having positive and inflation having a negative impact. These mixed results conclude the fact that sentiment is an important factor in investor decision-making of the Tehran stock exchange (TSE).

\section{Compliance with Ethical Standards}

\section{Conflict of Interest}

I Heshmatollah Asgari declare that I have no conflict of interest. I Hamed Najafi declare that I have no conflict of interest.

\section{Ethical Approval}

We declare that this article does not contain any studies with human participants or animals performed by any of the authors.

\section{References}

Ahmed, S., \& Ullah, N. (2013). Investor Sentiment and Stock Market Dynamics: A Case of Pakistan. Journal of Public Administration, Finance and Law, 4, 126-138.

Anusakumar, V. S., Ali, R., \& Wooi, H. C. (2012). Momentum and Investor Sentiment: Evidence from Asian Stock Markets.

Asem, E., Chung, J., Cui, X., \& Tian, G. (2016). Liquidity, investor sentiment and price discount of SEOs in Australia. International Journal of Managerial Finance, 12 (1), 25-51. https://doi.org/10.1108/IJMF-10-2013-0106

Baker, M., \& Jeffrey, W. (2006). Investor sentiment and the cross-section of stock returns. Journal of Finance, 61, 1645-1680. https://doi.org/10.1111/j.1540-6261.2006.00885.x

Bathia, D., \& Bredin, D. (2013). An examination of investor sentiment effect on G7 stock market returns. The European Journal of Finance, 19(9), 909-937. https://doi.org/10.1080/1351847X.2011.636834

Ben Aissia, D. (2016). Home and Foreign Investor Sentiment and The Stock Returns. The Quarterly Review of Economics and Finance, 59(C), 71-77. https://doi.org/10.1016/j.qref.2015.06.009

Brown, G. W. (1999). Volatility, Sentiment, and Noise Traders. Financial Analysts Journal, 55(2), 82-90. https://doi.org/10.2469/faj.v55.n2.2263

Canbaş, S., \& Yılmaz, K. S. (2009). Investor Sentiment and Stock Returns: Evidence from Turkey. Emerging Markets Finance and Trade, 45(4), 36-52. https://doi.org/10.2753/REE1540-496X450403

Chi, L., Zhuang, X., \& Song, D. (2012). Investor sentiment in the Chinese stock market: an empirical analysis. Applied Economics Letters, 19(4), 345-348. https://doi.org/10.1080/13504851.2011.577003

Chung, S.-L., Chi-Hsiou, H., \& Chung-Ying, Y. (2012). When does investor sentiment predict stock returns?. Journal of Empirical Finance, 19, 217-240. https://doi.org/10.1016/j.jempfin.2012.01.002

Dalika, N., \& Seetharam, Y. (2015). Sentiment and Returns: An Analysis of Investor Sentiment in the South African Market. Investment Management and Financial Innovations, 12(1), 261-267.

De Long, J. B., Andrei, S., Lawrence, H. S., \& Robert, J. W. (1990). Noise trader risk in financial markets. Journal of political Economy, 98, 703-738. https://doi.org/10.1086/261703

DeLong, J., Bradford, A. S., \& Lawrence, H., Summers, \& Robert, J. W. (1990). Noise Trader Risk in Financial Markets. Journal of Political Economy, 98(4), 703-38. https://doi.org/10.1086/261703 
Doojin, R., Hyeyoen, K., \& Heejin, Y. (2017). Investor sentiment, trading behavior and stock returns. Applied Economics Letters, 24(12), 826-830. https://doi.org/10.1080/13504851.2016.1231890

Ehrmann, M., \& Fratzscher, M. (2004). Taking stock: Monetary policy transmission to equity markets. Journal of Money, Credit and Banking 36, 719-737. https://doi.org/10.1353/mcb.2004.0063

Gholamreza, K., Ali, E. K. , Yasin, A., \& Saeed, H. (2014). Earnings Management and Underpricing of Initial Public Offerings (IPO), Evidence from Iran. International Business Research, 7(7), 156-163. https://doi.org/10.5539/ibr.v7n7p156

Grigaliūnienè, Z., \& Cibulskiene, D. (2010). Investor sentiment effect on stock returns in Scandinavian stock market. Economics and Management, 15, 929-940.

He, Zh., He, L., \& Wen, F. (2019). Risk Compensation and Market Returns: The Role of Investor Sentiment in the Stock Market. Emerging Markets Finance and Trade, 55(3), 704-718. https://doi.org/10.1080/1540496X.2018.1460724

Heejin, Y., Doojin, R., \& Doowon, R. (2017). Investor sentiment, asset returns and firm characteristics: Evidence from the Korean Stock Market. Investment Analysts Journal, 46(2), 132-147. https://doi.org/10.1080/10293523.2016.1277850

Iyer, S., \& Harper, J. (2017). Cash flow volatility and investor sentiment. Managerial Finance, 43(2), 178-192. https://doi.org/10.1108/MF-02-2016-0045

Johnson, E. J., \& Amos, T. (1983). Affect, generalization, and the perception of risk. Journal of Personality and Social Psychology, 45, 20. https://doi.org/10.1037/0022-3514.45.1.20

Kaplanski, G., Haim, L., Chris, V., \& Yulia, V.-M. (2015). Do happy people make optimistic investors?. Journal of Financial and Quantitative Analysis, 50, 145-168. https://doi.org/10.1017/S0022109014000416

Kim, T., \& Ha. A. (2010). Investor Sentiment and Market Anomalies. 23rd Australasian Finance and Banking Conference 2010 Paper, pp. 1-24. https://doi.org/10.2139/ssrn.1663649

Konstantinos, D. (2010). Terrorism activity, investor sentiment, and stock returns. Review of Financial Economics, 19(3), 128-135. https://doi.org/10.1016/j.rfe.2010.01.001

Kumar, A., \& Charles, L. (2006). Retail investor sentiment and return comovements. Journal of Finance, 61, 2451-2486. https://doi.org/10.1111/j.1540-6261.2006.01063.x

Kurov, A. (2010). Investor Sentiment and the Stock Market's Reaction to Monetary Policy. Journal of Banking \& Finance, 34(1), 139-149. https://doi.org/10.1016/j.jbankfin.2009.07.010

Kuzmina, J. (2010). Emotion's component of expectations in financial decision making. Baltic Journal of Management, 295-306. https://doi.org/10.1108/17465261011079721

Lee, C., Andrei, S., \& Richard, H. T. (1991). Investor sentiment and the closed-end fund puzzle. Journal of Finance 46, 75-109. https://doi.org/10.1111/j.1540-6261.1991.tb03746.x

Lioui, A., \& Paulo, M. (2014), Interest rate risk and the cross section of stock returns. Journal of Financial and Quantitative Analysis, 49, 483-511. https://doi.org/10.1017/S0022109014000131

Liston-Perez, D., \& Gutierrez, J. (2018). Dynamic analysis of sin stocks and investor sentiment. International Journal of Managerial Finance, 14 (5), 558-573. https://doi.org/10.1108/IJMF-01-2018-0001

Loewenstein, G. F., Elke, U. W., Christopher, K. H., \& Ned, W. (2001). Risk as feelings. Psychological Bulletin, 127, 267. https://doi.org/10.1037/0033-2909.127.2.267

Mahdi, F., Alireza, A., \& Jalal, A. (2013). An Empirical Analysis for Abnormal Returns from Initial Public Offerings (IPOs): evidence of Iranian oil and chemical industries. International Journal of Accounting and Financial Reporting, 3(1). https://doi.org/10.5296/ijafr.v3i1.3048

Mian, G. M., \& Srinivasan, S. (2012). Investor sentiment and stock market response to earnings news. Accounting Review, 87, 1357-1384. https://doi.org/10.2308/accr-50158

Padungsaksawasdi, C. (2019). On the dynamic relationship between gold investor sentiment index and stock market: A sectoral analysis. International Journal of Managerial Finance, Vol. ahead-of-print No. ahead-of-print. https://doi.org/10.1108/IJMF-11-2018-0334

Rupande, L., Muguto, H. T., Muzindutsi, P. F., \&Yang, Zh. (2019). Investor sentiment and stock return volatility: 
Evidence from the Johannesburg Stock Exchange. Cogent Economics \& Finance, 7(1). https://doi.org/10.1080/23322039.2019.1600233

Schmeling, M. (2009). Investor sentiment and stock returns: Some international evidence. Journal of Empirical Finance, 16(3), 394-408. https://doi.org/10.1016/j.jempfin.2009.01.002

Shen, J., Jianfeng, Y., \& Shen, Z. (2017). Investor sentiment and economic forces. Journal of Monetary Economics, 86, 1-21. https://doi.org/10.1016/j.jmoneco.2017.01.001

Shuming, L. (2015). Investor Sentiment and Stock Market Liquidity. Journal of Behavioral Finance, 16(1), 51-67. https://doi.org/10.1080/15427560.2015.1000334

Smales, L. A. (2017). The importance of fear: investor sentiment and stock market returns. Applied Economics, 49(34), 3395-3421. https://doi.org/10.1080/00036846.2016.1259754

Stambaugh, R. F., Jianfeng, Y., \& Yu, Y. (2012). The short of it: Investor sentiment and anomalies. Journal of Financial Economics, 104, 288-302. https://doi.org/10.1016/j.jfineco.2011.12.001

Thorbecke, W. (1997). On stock market returns and monetary policy. Journal of Finance, 52, 635-654. https://doi.org/10.1111/j.1540-6261.1997.tb04816.x

Tran, T. U. T., \& Nguyen, N. Y. T. (2013). The Effect of Investor Sentiment on Stock Returns in Norway and Vietnam (BI Norwegian Business School - Master Thesis, PP. 141- 155).

Trichilli, Y., Boujelbène Abbes, M., \& Masmoudi, A. (2020). Predicting the effect of Googling investor sentiment on Islamic stock market returns: A five-state hidden Markov model. International Journal of Islamic and Middle Eastern Finance and Management, ahead-of-print. https://doi.org/10.1108/IMEFM-07-2018-0218

Yu, J., \& Yu, Y. (2011). Investor sentiment and the mean-variance relation. Journal of Financial Economics, 100, 367-381. https://doi.org/10.1016/j.jfineco.2010.10.011

Zhang. Q., \& Yang, S-e. (2009). Noise Trading, Investor Sentiment Volatility, and Stock Returns. Systems Engineering - Theory \& Practice, 29(3), 40-47. https://doi.org/10.1016/S1874-8651(10)60010-5

\section{Appendix: Table and calculations:}

\section{Calculations:}

\section{Cointegration test}

Date: 06/26/20 Time: 17:36

Sample (adjusted): 2010Q3 2019Q4

Included observations: 38 after adjustments

Trend assumption: Linear deterministic trend

Series: TSER SENTI INF GEXP GDP

Lags interval (in first differences): 1 to 1

Unrestricted Cointegration Rank Test (Trace)

\begin{tabular}{ccccc}
\hline \hline $\begin{array}{c}\text { Hypothesized } \\
\text { No. of CE(s) }\end{array}$ & Eigenvalue & $\begin{array}{c}\text { Trace } \\
\text { Statistic }\end{array}$ & $\begin{array}{c}0.05 \\
\text { Critical Value }\end{array}$ & Prob.** \\
\hline \hline None * & 0.571014 & 80.56293 & 69.81889 & 0.0054 \\
At most 1 * & 0.453555 & 48.40232 & 47.85613 & 0.0444 \\
At most 2 & 0.346889 & 25.43810 & 29.79707 & 0.1464 \\
At most 3 & 0.118052 & 9.249784 & 15.49471 & 0.3428 \\
At most 4 & 0.111121 & 4.476160 & 3.841466 & 0.0344 \\
\hline \hline
\end{tabular}


Trace test indicates 2 cointegrating eqn(s) at the 0.05 level

$*$ denotes rejection of the hypothesis at the 0.05 level

**MacKinnon-Haug-Michelis (1999) p-values

Unrestricted Cointegration Rank Test (Maximum Eigenvalue)

\begin{tabular}{ccccc}
\hline \hline $\begin{array}{c}\text { Hypothesized } \\
\text { No. of CE(s) }\end{array}$ & Eigenvalue & $\begin{array}{c}\text { Max-Eigen } \\
\text { Statistic }\end{array}$ & $\begin{array}{c}0.05 \\
\text { Critical Value }\end{array}$ & Prob. $^{* *}$ \\
\hline \hline None & 0.571014 & 32.16061 & 33.87687 & 0.0790 \\
At most 1 & 0.453555 & 22.96422 & 27.58434 & 0.1750 \\
At most 2 & 0.346889 & 16.18832 & 21.13162 & 0.2141 \\
At most 3 & 0.118052 & 4.773624 & 14.26460 & 0.7701 \\
At most 4 * & 0.111121 & 4.476160 & 3.841466 & 0.0344 \\
\hline \hline
\end{tabular}

Max-eigenvalue test indicates no cointegration at the 0.05 level

$*$ denotes rejection of the hypothesis at the 0.05 level

**MacKinnon-Haug-Michelis (1999) p-values

Unrestricted Cointegrating Coefficients (normalized by $b^{*} * \mathrm{~S} 11 * \mathrm{~b}=\mathrm{I}$ ):

\begin{tabular}{ccccc}
\hline \hline TSER & SENTI & INF & GEXP & \multicolumn{1}{c}{ GDP } \\
-0.002021 & $4.04 \mathrm{E}-05$ & 0.107107 & 0.328742 & $5.66 \mathrm{E}-12$ \\
0.000625 & $-1.55 \mathrm{E}-05$ & -0.013999 & -1.539120 & $-6.06 \mathrm{E}-12$ \\
-0.002601 & $2.98 \mathrm{E}-05$ & -0.051284 & -0.179212 & $1.36 \mathrm{E}-11$ \\
-0.000624 & $1.89 \mathrm{E}-06$ & -0.084796 & -0.176603 & $-3.61 \mathrm{E}-12$ \\
0.000535 & $-7.53 \mathrm{E}-05$ & 0.023046 & 0.161895 & $3.25 \mathrm{E}-12$ \\
\hline \hline
\end{tabular}

Unrestricted Adjustment Coefficients (alpha):

\begin{tabular}{crrrrr}
\hline \hline D(TSER) & -75.41944 & 1.764554 & 48.19605 & -21.82461 & -32.04446 \\
$\mathrm{D}(\mathrm{SENTI})$ & -2371.449 & -114.9097 & 449.9758 & -339.6928 & 1517.033 \\
$\mathrm{D}(\mathrm{INF})$ & -4.768153 & -2.514814 & 0.989853 & 1.850989 & -0.316451 \\
$\mathrm{D}(\mathrm{GEXP})$ & 0.027284 & 0.404442 & 0.117145 & 0.021874 & -0.022678 \\
$\mathrm{D}(\mathrm{GDP})$ & $-6.48 \mathrm{E}+09$ & $2.16 \mathrm{E}+09$ & $-2.10 \mathrm{E}+10$ & $1.59 \mathrm{E}+09$ & $2.05 \mathrm{E}+09$ \\
\hline \hline & & & & \\
1 Cointegrating Equation(s): & Log likelihood & -1759.295 & & \\
\hline \hline
\end{tabular}

Normalized cointegrating coefficients (standard error in parentheses)

$\begin{array}{ccccc}\text { TSER } & \text { SENTI } & \text { INF } & \text { GEXP } & \text { GDP } \\ 1.000000 & -0.019996 & -53.00104 & -162.6754 & -2.80 \mathrm{E}-09 \\ & (0.00530) & (11.4157) & (121.527) & (7.5 \mathrm{E}-10)\end{array}$


Adjustment coefficients (standard error in parentheses)

$\begin{array}{cc}\text { D(TSER) } & 0.152411 \\ & (0.05652) \\ \mathrm{D}(\text { SENTI }) & 4.792330 \\ & (1.86934) \\ \mathrm{D}(\mathrm{INF}) & 0.009636 \\ & (0.00290) \\ \mathrm{D}(\mathrm{GEXP}) & -5.51 \mathrm{E}-05 \\ & (0.00023) \\ \mathrm{D}(\mathrm{GDP}) & 13086071 \\ & (1.3 \mathrm{E}+07)\end{array}$

\begin{tabular}{ccccc}
\hline \hline 2 Cointegrating Equation(s): & Log likelihood & -1747.812 & \\
\hline \hline \multicolumn{2}{l}{ Normalized cointegrating coefficients } & (standard error in parentheses) & \\
TSER & SENTI & INF & GEXP & GDP \\
1.000000 & 0.000000 & -179.3658 & 9347.818 & $2.57 \mathrm{E}-08$ \\
& & $(201.544)$ & $(2149.50)$ & $(1.1 \mathrm{E}-08)$ \\
0.000000 & 1.000000 & -6319.621 & 475628.9 & $1.43 \mathrm{E}-06$ \\
& & $(9929.13)$ & $(105896)$. & $(5.6 \mathrm{E}-07)$ \\
\hline
\end{tabular}

\begin{tabular}{ccc}
\hline Adjustment coefficients (standard error in parentheses) \\
D(TSER) & 0.153513 & -0.003075 \\
& $(0.05916)$ & $(0.00121)$ \\
D(SENTI) & 4.720568 & -0.094043 \\
& $(1.95608)$ & $(0.04003)$ \\
D(INF) & 0.008065 & -0.000154 \\
& $(0.00288)$ & $(5.9 \mathrm{E}-05)$ \\
D(GEXP) & 0.000197 & $-5.17 \mathrm{E}-06$ \\
& $(0.00019)$ & $(3.9 \mathrm{E}-06)$ \\
D(GDP) & 14434739 & -295158.5 \\
& $(1.4 \mathrm{E}+07)$ & $(287236)$.
\end{tabular}

\begin{tabular}{|c|c|c|c|c|}
\hline \multicolumn{2}{|c|}{3 Cointegrating Equation(s): } & Log likelihood & \multicolumn{2}{|l|}{-1739.718} \\
\hline \multicolumn{5}{|c|}{ Normalized cointegrating coefficients (standard error in parentheses) } \\
\hline TSER & SENTI & INF & GEXP & GDP \\
\hline 1.000000 & 0.000000 & 0.000000 & $\begin{array}{l}3918.637 \\
(797.252)\end{array}$ & $\begin{array}{l}5.05 \mathrm{E}-09 \\
(4.3 \mathrm{E}-09)\end{array}$ \\
\hline 0.000000 & 1.000000 & 0.000000 & $\begin{array}{l}284341.8 \\
(56204.1)\end{array}$ & $\begin{array}{c}6.99 \mathrm{E}-07 \\
(3.1 \mathrm{E}-07)\end{array}$ \\
\hline 0.000000 & 0.000000 & 1.000000 & $\begin{array}{r}-30.26877 \\
(7.04183)\end{array}$ & $\begin{array}{r}-1.15 \mathrm{E}-10 \\
(3.8 \mathrm{E}-11)\end{array}$ \\
\hline
\end{tabular}

Adjustment coefficients (standard error in parentheses) 


\begin{tabular}{|c|c|c|c|c|}
\hline D(TSER) & $\begin{array}{l}0.028144 \\
(0.08916)\end{array}$ & $\begin{array}{r}-0.001641 \\
(0.00140)\end{array}$ & $\begin{array}{r}-10.57432 \\
(3.18006)\end{array}$ & \\
\hline $\mathrm{D}(\mathrm{SENTI})$ & $\begin{array}{l}3.550082 \\
(3.08865)\end{array}$ & $\begin{array}{r}-0.080653 \\
(0.04839)\end{array}$ & $\begin{array}{r}-275.4663 \\
(110.159)\end{array}$ & \\
\hline $\mathrm{D}(\mathrm{INF})$ & $\begin{array}{l}0.005490 \\
(0.00452)\end{array}$ & $\begin{array}{r}-0.000124 \\
(7.1 \mathrm{E}-05)\end{array}$ & $\begin{array}{r}-0.526260 \\
(0.16138)\end{array}$ & \\
\hline $\mathrm{D}(\mathrm{GEXP})$ & $\begin{array}{r}-0.000107 \\
(0.00029)\end{array}$ & $\begin{array}{r}-1.68 \mathrm{E}-06 \\
(4.5 \mathrm{E}-06)\end{array}$ & $\begin{array}{r}-0.008747 \\
(0.01035)\end{array}$ & \\
\hline $\mathrm{D}(\mathrm{GDP})$ & $\begin{array}{l}69013065 \\
(1.8 \mathrm{E}+07)\end{array}$ & $\begin{array}{r}-919556.6 \\
(286926 .)\end{array}$ & $\begin{array}{l}3.52 \mathrm{E}+08 \\
(6.5 \mathrm{E}+08)\end{array}$ & \\
\hline \multicolumn{2}{|c|}{4 Cointegrating Equation(s): } & Log likelihood & -1737.331 & \\
\hline \multicolumn{5}{|c|}{ Normalized cointegrating coefficients (standard error in parentheses) } \\
\hline \multirow{2}{*}{$\begin{array}{c}\text { TSER } \\
1.000000\end{array}$} & SENTI & INF & GEXP & GDP \\
\hline & 0.000000 & 0.000000 & 0.000000 & $\begin{array}{r}-4.91 \mathrm{E}-08 \\
(1.8 \mathrm{E}-08)\end{array}$ \\
\hline 0.000000 & 1.000000 & 0.000000 & 0.000000 & $\begin{array}{r}-3.23 \mathrm{E}-06 \\
(1.3 \mathrm{E}-06)\end{array}$ \\
\hline 0.000000 & 0.000000 & 1.000000 & 0.000000 & $\begin{array}{l}3.03 \mathrm{E}-10 \\
(1.3 \mathrm{E}-10)\end{array}$ \\
\hline 0.000000 & 0.000000 & 0.000000 & 1.000000 & $\begin{array}{l}1.38 \mathrm{E}-11 \\
(4.6 \mathrm{E}-12)\end{array}$ \\
\hline \multicolumn{5}{|c|}{ Adjustment coefficients (standard error in parentheses) } \\
\hline D(TSER) & $\begin{array}{l}0.041757 \\
(0.08970)\end{array}$ & $\begin{array}{r}-0.001682 \\
(0.00138)\end{array}$ & $\begin{array}{r}-8.723680 \\
(3.85595)\end{array}$ & $\begin{array}{r}-32.29237 \\
(41.9247)\end{array}$ \\
\hline $\mathrm{D}(\mathrm{SENTI})$ & $\begin{array}{l}3.761955 \\
(3.13475)\end{array}$ & $\begin{array}{r}-0.081295 \\
(0.04832)\end{array}$ & $\begin{array}{r}-246.6617 \\
(134.750)\end{array}$ & $\begin{array}{r}-623.3844 \\
(1465.10)\end{array}$ \\
\hline $\mathrm{D}(\mathrm{INF})$ & $\begin{array}{l}0.004336 \\
(0.00446)\end{array}$ & $\begin{array}{r}-0.000121 \\
(6.9 \mathrm{E}-05)\end{array}$ & $\begin{array}{r}-0.683216 \\
(0.19175)\end{array}$ & $\begin{array}{l}1.798827 \\
(2.08483)\end{array}$ \\
\hline $\mathrm{D}(\mathrm{GEXP})$ & $\begin{array}{r}-0.000121 \\
(0.00029)\end{array}$ & $\begin{array}{r}-1.64 \mathrm{E}-06 \\
(4.5 \mathrm{E}-06)\end{array}$ & $\begin{array}{r}-0.010602 \\
(0.01267)\end{array}$ & $\begin{array}{r}-0.638373 \\
(0.13778)\end{array}$ \\
\hline $\mathrm{D}(\mathrm{GDP})$ & $\begin{array}{l}68021738 \\
(1.9 \mathrm{E}+07)\end{array}$ & $\begin{array}{r}-916548.6 \\
(286720 .)\end{array}$ & $\begin{array}{l}2.17 \mathrm{E}+08 \\
(8.0 \mathrm{E}+08)\end{array}$ & $\begin{array}{c}-1.97 \mathrm{E}+09 \\
(8.7 \mathrm{E}+09)\end{array}$ \\
\hline
\end{tabular}




\section{VAR estimation}

Vector Autoregression Estimates

Date: 06/26/20 Time: 20:26

Sample (adjusted): 2010Q3 2019Q4

Included observations: 38 after adjustments

Standard errors in ( ) \& t-statistics in [ ]

\begin{tabular}{|c|c|c|c|c|c|}
\hline & TSER & SENTI & INF & GDP & GEXP \\
\hline \multirow[t]{3}{*}{ TSER(-1) } & 1.206666 & -7.908452 & -0.001950 & -24432307 & 0.000438 \\
\hline & $(0.21293)$ & $(7.28320)$ & $(0.01084)$ & $(4.5 \mathrm{E}+07)$ & $(0.00072)$ \\
\hline & [ 5.66691] & {$[-1.08585]$} & {$[-0.17991]$} & {$[-0.54111]$} & {$[0.61174]$} \\
\hline \multirow[t]{3}{*}{ TSER(-2) } & -0.182045 & 12.48164 & 0.006117 & 93547784 & -0.000571 \\
\hline & $(0.26083)$ & $(8.92146)$ & $(0.01328)$ & $(5.5 \mathrm{E}+07)$ & $(0.00088)$ \\
\hline & {$[-0.69795]$} & [ 1.39906$]$ & {$[0.46062]$} & [ 1.69138$]$ & {$[-0.65103]$} \\
\hline \multirow[t]{3}{*}{ SENTI(-1) } & -0.002465 & 0.569454 & $-3.72 \mathrm{E}-05$ & -410136.9 & $2.97 \mathrm{E}-07$ \\
\hline & $(0.00496)$ & $(0.16963)$ & $(0.00025)$ & $(1051641)$ & $(1.7 \mathrm{E}-05)$ \\
\hline & {$[-0.49695]$} & [ 3.35697$]$ & {$[-0.14728]$} & {$[-0.39000]$} & {$[0.01777]$} \\
\hline \multirow[t]{3}{*}{ SENTI(-2) } & 0.003196 & 0.234983 & $-5.97 \mathrm{E}-05$ & -660473.0 & $-2.31 \mathrm{E}-07$ \\
\hline & $(0.00479)$ & $(0.16396)$ & $(0.00024)$ & (1016448) & $(1.6 \mathrm{E}-05)$ \\
\hline & {$[0.66681]$} & {$[1.43320]$} & {$[-0.24454]$} & {$[-0.64979]$} & {$[-0.01433]$} \\
\hline \multirow[t]{3}{*}{$\operatorname{INF}(-1)$} & -0.008477 & -10.19515 & 0.645137 & $1.96 \mathrm{E}+08$ & -0.010598 \\
\hline & $(3.95200)$ & $(135.176)$ & $(0.20121)$ & $(8.4 \mathrm{E}+08)$ & $(0.01330)$ \\
\hline & {$[-0.00214]$} & {$[-0.07542]$} & [ 3.20622] & {$[0.23365]$} & {$[-0.79709]$} \\
\hline \multirow[t]{3}{*}{$\mathrm{INF}(-2)$} & -9.453696 & -201.5052 & -0.335646 & 68779449 & -0.000527 \\
\hline & $(4.07221)$ & (139.287) & $(0.20733)$ & $(8.6 \mathrm{E}+08)$ & $(0.01370)$ \\
\hline & {$[-2.32151]$} & {$[-1.44669]$} & {$[-1.61886]$} & {$[0.07965]$} & {$[-0.03844]$} \\
\hline \multirow[t]{3}{*}{$\operatorname{GDP}(-1)$} & $-8.20 \mathrm{E}-10$ & $-7.60 \mathrm{E}-08$ & $-7.68 \mathrm{E}-11$ & 0.983133 & $-2.06 \mathrm{E}-13$ \\
\hline & $(9.7 \mathrm{E}-10)$ & $(3.3 \mathrm{E}-08)$ & $(5.0 \mathrm{E}-11)$ & $(0.20656)$ & $(3.3 \mathrm{E}-12)$ \\
\hline & {$[-0.84143]$} & {$[-2.28214]$} & {$[-1.54785]$} & [ 4.75959] & {$[-0.06271]$} \\
\hline \multirow[t]{3}{*}{ GDP(-2) } & $1.01 \mathrm{E}-09$ & $7.56 \mathrm{E}-08$ & $7.07 \mathrm{E}-11$ & -0.316451 & $-6.57 \mathrm{E}-13$ \\
\hline & $(8.5 \mathrm{E}-10)$ & $(2.9 \mathrm{E}-08)$ & $(4.3 \mathrm{E}-11)$ & $(0.17959)$ & $(2.8 \mathrm{E}-12)$ \\
\hline & [ 1.19237$]$ & [ 2.60873] & [ 1.64009$]$ & {$[-1.76208]$} & {$[-0.23070]$} \\
\hline \multirow[t]{3}{*}{$\operatorname{GEXP}(-1)$} & -27.39596 & -2115.628 & -0.530298 & $-1.21 \mathrm{E}+09$ & 0.845094 \\
\hline & $(52.8905)$ & (1809.08) & $(2.69289)$ & $(1.1 \mathrm{E}+10)$ & $(0.17794)$ \\
\hline & {$[-0.51798]$} & {$[-1.16945]$} & {$[-0.19693]$} & {$[-0.10764]$} & [ 4.74932] \\
\hline \multirow[t]{3}{*}{ GEXP(-2) } & -10.08426 & 1737.845 & 2.277894 & $-4.35 \mathrm{E}+08$ & -0.487138 \\
\hline & (48.6159) & $(1662.87)$ & $(2.47525)$ & $(1.0 \mathrm{E}+10)$ & $(0.16356)$ \\
\hline & {$[-0.20743]$} & [ 1.04509$]$ & [ 0.92027$]$ & {$[-0.04217]$} & {$[-2.97836]$} \\
\hline \multirow[t]{3}{*}{$\mathrm{C}$} & 292.4464 & 8687.100 & 3.361992 & $-4.85 \mathrm{E}+10$ & 3.224187 \\
\hline & $(256.185)$ & $(8762.62)$ & $(13.0435)$ & $(5.4 \mathrm{E}+10)$ & $(0.86189)$ \\
\hline & [ 1.14155$]$ & [ 0.99138$]$ & {$[0.25775]$} & {$[-0.89319]$} & [3.74085] \\
\hline
\end{tabular}




\begin{tabular}{lrrrrr} 
R-squared & 0.982741 & 0.938186 & 0.406363 & 0.959914 & 0.651759 \\
Adj. R-squared & 0.976349 & 0.915292 & 0.186497 & 0.945068 & 0.522781 \\
Sum sq. resids & 776070.7 & $9.08 \mathrm{E}+08$ & 2011.799 & $3.49 \mathrm{E}+22$ & 8.784041 \\
S.E. equation & 169.5387 & 5798.959 & 8.631980 & $3.60 \mathrm{E}+10$ & 0.570381 \\
F-statistic & 153.7388 & 40.97924 & 1.848234 & 64.65566 & 5.053248 \\
Log likelihood & -242.4835 & -376.7129 & -129.3344 & -971.0322 & -26.09132 \\
Akaike AIC & 13.34124 & 20.40594 & 7.386023 & 51.68590 & 1.952175 \\
Schwarz SC & 13.81528 & 20.87998 & 7.860061 & 52.15994 & 2.426213 \\
Mean dependent & 2881.983 & 60208.19 & 19.58125 & $2.07 \mathrm{E}+11$ & 3.953613 \\
S.D. dependent & 1102.402 & 19924.47 & 9.570420 & $1.53 \mathrm{E}+11$ & 0.825670 \\
\hline \hline Determinant resid covariance (dof adj.) & $1.74 \mathrm{E}+34$ & & & \\
Determinant resid covariance & $3.15 \mathrm{E}+33$ & & & \\
Log likelihood & -1735.093 & & & \\
Akaike information criterion & 94.21544 & & & \\
Schwarz criterion & 96.58563 & & & \\
Number of coefficients & 55 & & & \\
\hline
\end{tabular}

\section{Causality test}

VAR Granger Causality/Block Exogeneity Wald Tests

Date: $06 / 26 / 20$ Time: 22:37

Sample: 2010Q1 2020Q2

Included observations: 38

Dependent variable: TSER

\begin{tabular}{llll}
\hline \hline Excluded & Chi-sq & df & Prob. \\
\hline \hline SENTI & 0.470777 & 2 & 0.0379 \\
INF & 7.035414 & 2 & 0.0297 \\
GDP & 1.625219 & 2 & 0.4437 \\
GEXP & 0.733260 & 2 & 0.6931 \\
\hline \hline All & & 6 & -- \\
\hline \hline Dependent variable: SENTI & & & \\
\hline \hline Excluded & & df & Prob. \\
\hline \hline TSER & Chi-sq & 2 & 0.0038 \\
INF & 2.402763 & 2 & 0.0332 \\
GDP & 2.874543 & 2 & 0.2376 \\
GEXP & 6.807621 & 2 & 0.4656 \\
\hline \hline
\end{tabular}


All

6

Dependent variable: INF

\begin{tabular}{llll}
\hline \hline Excluded & Chi-sq & df & Prob. \\
\hline \hline TSER & 0.757180 & 2 & 0.4868 \\
SENTI & 0.576967 & 2 & 0.7494 \\
GDP & 2.734818 & 2 & 0.0254 \\
GEXP & 1.083398 & 2 & 0.0481 \\
\hline \hline All & & 6 & --- \\
\hline \hline Dependent variable: GDP & & & \\
\hline \hline Excluded & Chi-sq & df & Prob. \\
\hline \hline TSER & 12.22226 & 2 & 0.0022 \\
SENTI & 4.063300 & 2 & 0.1311 \\
INF & 0.102923 & 2 & 0.9498 \\
GEXP & 0.031329 & 2 & 0.0098 \\
\hline \hline All & 12.81046 & 8 & 0.1185 \\
\hline \hline
\end{tabular}

Dependent variable: GEXP

\begin{tabular}{llll}
\hline \hline Excluded & Chi-sq & df & Prob. \\
\hline \hline TSER & 0.423838 & 2 & 0.8090 \\
SENTI & 0.000320 & 2 & 0.9998 \\
INF & 0.869196 & 2 & 0.6475 \\
GDP & 0.375821 & 2 & 0.0288 \\
\hline \hline All & & 6 & --- \\
\hline \hline
\end{tabular}

Test statistics not available for lag coefficients with restrictions

\section{Copyrights}

Copyright for this article is retained by the author(s), with first publication rights granted to the journal.

This is an open-access article distributed under the terms and conditions of the Creative Commons Attribution license (http://creativecommons.org/licenses/by/4.0/). 